\title{
SURGICAL TREATMENT OF ANAL STENOSIS: ASSESSMENT OF 77 ANOPLASTIES
}

\author{
Angelita Habr-Gama, Carlos Walter Sobrado, Sergio Eduardo Alonso de Araújo, \\ Sergio Carlos Nahas, Ingrid Birbojm, Caio Sergio Rizkallah Nahas and Desidério \\ Roberto Kiss
}

HABR-GAMA A et al. Surgical treatment of anal stenosis: assessment of 77 anoplasties. CLINICS 60(1):17-20, 2005.

PURPOSE: Anal stenosis is a rare, incapacitating, and challenging condition, occurring mainly after hemorrhoidectomy, for which several surgical techniques have been devised. The purpose of this study was to describe early and late (1 year) results of 77 anoplasty operations performed in the Colorectal Unit of our institution.

METHODS: From 1977 to 2002, 77 patients with moderate to severe anal stenosis underwent surgery using two sliding graft techniques: 58 underwent Sarner's operation and 19 underwent Musiari's technique. Bilateral flaps were used in 7 patients.

RESULTS: Early morbidity was due to pruritus occurring in 2 patients, urinary infection in 1, and temporary incontinence in 1 patient. One patient needed early reoperation following suture line dehiscence. Late results (1 year) were classified as good in 67 cases (87\%). There was no reoperation due to recurrence of stenosis.

Conclusion: The ease of performance, good functional results, and lack of severe complications show that Sarner's and Musiari's flap advancement techniques are effective and safe methods for surgical correction of anal stenosis, particularly when cutaneous fibrosis plays a major role in its etiology.

KEYWORDS: Anal stenosis. Anoplasty. Flap advancement.

Anal stenosis is an uncommon and disabling condition. It represents an abnormal narrowing of the anal canal to a varying extent due to stricture of the epithelial lining that has been replaced by fibrous connective tissue. ${ }^{1}$ Although anal stenosis may occur without previous anorectal surgery, it usually results from surgical procedures carried out overzealously without the required technical knowledge, most commonly after hemorrhoidectomy., ${ }^{2,3}$

Effective management of anal stenosis is challenging. Symptomatic mild stenosis may be conservatively managed with diet changes, fiber supplements, and stool softeners. Numerous surgical techniques have been devised for the treatment of moderate to severe anal stenosis that is refractory to conservative treatment, with good results reported

From the Colorectal Unit, Hospital das Clínicas, Faculty of Medicine, University of São Paulo - São Paulo/SP, Brazil.

E-mail: sobrado@iconet.com.br

Received for publication on April 06, 2004.

Accepted for publication on June 28, 2004. in several series. ${ }^{1,4-21}$ They include partial anal sphincterotomy with stricture release and several forms of plastic surgery through advancement and rotational flaps involving skin, mucosa, or both.

In this study, early and late results are presented regarding 77 consecutive patients treated for severe cicatricial stricture of the anus who underwent sliding skin grafts from 1977 to 2002 using techniques developed by Sarner ${ }^{6}$ and Musiari. ${ }^{4}$ The surgical team performed either technique according to its preference, surgical conditions, and previous experience. ${ }^{8,16}$

\section{MATERIALS AND METHODS}

The study included 77 consecutive patients with anal stenosis who underwent anoplasty for anal stenosis from 1977 to 2002.

According to the classification proposed by Milson and Mazier, ${ }^{12}$ all patients had moderate to severe anal stenosis. 
There were 49 women and 28 men ranging in age from 25 to 83 (mean age, 44 ).

In all patients, digital examination was not possible. Fifty-nine (77\%) complained of obstructive defecation, 53 (69\%) of painful evacuation, and 18 (23\%) of frequent episodes of bleeding during defecation.

Hemorrhoidectomy was the most common cause for the stenosis (Table 1). The time elapsed from hemorrhoidectomy to anoplasty varied from 2 months to 15 years. None of the patients who had a previous hemorrhoidectomy had undergone that surgery at our institution.

Table 1 - Etiology of Anal Stenosis.

\begin{tabular}{lc}
\hline Causes & Number of Cases \\
\hline Hemorrhoidectomy & 63 \\
Laxative abuse & 6 \\
Fissurectomy & 3 \\
Fistulectomy & 2 \\
Excision and electrocoagulation of condyloma & 1 \\
Correction of congenital malformation & 1 \\
Debridement after Fournier's gangrene & 1 \\
\hline
\end{tabular}

The night before surgery, all patients had a cleansing enema. A complete proctologic examination was carried out soon after anesthesia was administered, when possible. All patients underwent surgery in the lithotomy position under regional anesthesia. Antibiotic prophylaxis was routinely used (chloramphenicol or cefoxitin) for a 24-hour period.

The operation was initiated by the evaluation and excision of the distal transitional zone and anal scars with underlying partial internal sphincterotomy, the extent of which varied according to the longitudinal length of the scar. A rectangular flap was then planned. Its cranial margin was at the scar excision. The flap was at least $1 \mathrm{~cm}$ wide, and its length did not measure more than 3 times the width to prevent necrosis. The flap was then mobilized to replace the lining at the original scar location. Its cranial border was sutured without tension to the distal rectal mucosa margin. Hemostasis was carefully attended to. At the surgeon's choice, lateral margins were sutured or not and the caudal margin of the flap was incised (Sarner's technique — Figure 1) or not (Musiari's technique - Figure 2). In cases in which the skin flap was not tension-free while the surgeon tried to perform Musiari's technique, it was converted to Sarner's technique to avoid flap dehiscence and contracture. Estimates of blood supply and degree of tension in the flap were the main determinants of these suturing options.

Sarner's anoplasty was performed in 58 patients, and Musiari's technique was used in 19. Depending upon the degree of anal opening after the mobilization and fixation of the first flap, a second contralateral flap (sagittal or coronal) was sometimes used. Bilateral flaps were used in 7 patients who underwent Sarner's operation.

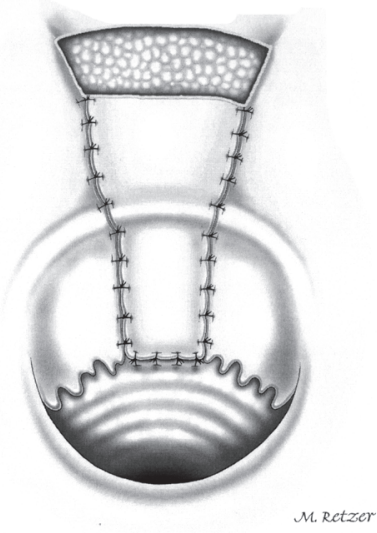

Figure 1 - Sarner's anoplasty. After dissection of a rectangular cutaneous flap, its distal border is incised and the proximal border is sutured to the fibrotic tissue resection line.

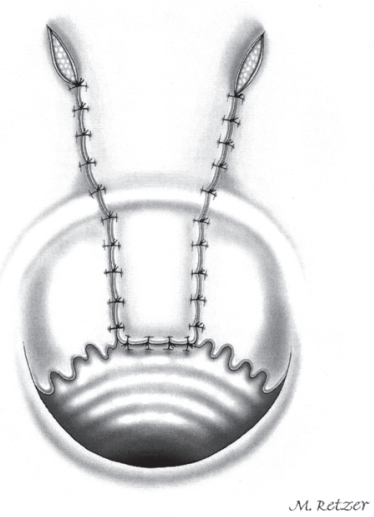

Figure 2 - Musiari's anoplasty. After an incision made in the fibrotic area, a rectangular flap is created and suturing to the line of resection is performed without tension.

Patients were discharged 48 hours after the procedure. A high-fiber diet combined with bulk laxatives was recommended

After discharge, all patients were evaluated on a weekly basis until complete operative wound closure was obtained. All patients were seen after 6 months and after 1 year. Immediate postoperative pain was minimal in the majority of patients.

Results were considered good (successful outcome) when spontaneous evacuation following high-fiber meals or bulk laxatives was observed. Results were considered unsatisfactory (unsuccessful outcome) when patients reported frequent painful evacuation for whom oral osmotic laxatives, suppositories, or enema administration were required and for those who required a late reoperation.

\section{RESULTS}

Temporary incontinence with gas and liquid stool lasting up to 3 months was observed in 1 patient. Urinary infection was observed in another. Moderate pruritus that subsided after 3 weeks was observed in 2 patients. Suture flap 
dehiscence with ischemic contracture was observed in 1 patient who received a Sarner's flap. This patient underwent early reoperation. Excision of the ischemic border and new suturing of the flap was performed.

The mean time until complete wound healing was 4 weeks, varying from 3 to 6 weeks. Complete wound closure was observed in all patients.

Results were considered good when spontaneous evacuation following high-fiber meals or bulk laxatives was observed. In this consecutive series, good results were observed in $51(88 \%)$ patients after Sarner's operation and in $16(84 \%)$ patients after Musiari's operation, an overall $87 \%$ success rate (Table 2). Seven patients in the Sarner's operation group and 3 in the Musiari's group were included in the unsuccessful outcome group.

\section{DISCUSSION}

Anal stenosis, although rare, is one of the most feared and disabling complications of anorectal surgery. Most cases of mild to moderate narrowing can be managed conservatively. Nevertheless, when conservative treatment is not effective in facilitating evacuation and reducing pain, surgical treatment is warranted.

A number of corrective surgical procedures have been designed aiming to bring a healthy lining to the narrowed portion of the anal canal ${ }^{4-21}$ (Table 3). Since more complex techniques (such as S-plasty) ${ }^{5}$ have now been abandoned

Table 2 - Early and late (1 year) results after anoplasty.

\begin{tabular}{lll}
\hline & $\begin{array}{l}\text { Sarner's } \\
\text { Anoplasty }\end{array}$ & $\begin{array}{l}\text { Musiari's } \\
\text { Anoplasty }\end{array}$ \\
\hline Healing & $58(100 \%)$ & $19(100 \%)$ \\
Early reoperation & $1(1.7 \%)$ & 0 \\
Late reoperation & 0 & 0 \\
Good results after 1 year & $51(88 \%)$ & $16(84 \%)$ \\
\hline
\end{tabular}

due to high morbidity and longer hospital stay, easier techniques are still being performed with good results (Table 3 ). The ideal procedure should be simple, should lead to no or minimal early and late morbidity, and should restore anal function with a good long-term outcome. ${ }^{21}$ In patients with a moderate degree of stenosis, a single sphincterotomy may be sufficient treatment; however, when fibrosis is intense, it might be an obstacle to the physiologic anal dilation occurring during evacuation, indicating the need for the interposition of normal tissue.

In this study, results obtained in 77 patients with severe anal stenosis who underwent anoplasty with a skin flap advancement were presented. None of the 63 patients who had a previous hemorrhoidectomy had undergone that surgery at our institution. They had undergone surgery over a period of 25 years, which partially explains the time interval required for operating on a relatively small number of patients, and made adequate follow-up a difficult task. Notwithstanding, a oneyear follow-up was obtained for all patients.

Musiari's $s^{4}$ and Sarner's ${ }^{6}$ techniques for anoplasty are simple and undemanding operations associated with low morbidity and good functional results. . $^{8,15,16,20}$

Complications from these procedures include flap necrosis from loss of vascular supply, suture line dehiscence from excessive tension, donor site problems, local infection, urinary tract infection, incontinence, and re-stenosis. In this series, only minor complications (pruritus in 2 patients and temporary anal incontinence in 1) were observed. One patient underwent early reoperation due to suture line dehiscence in order to prevent flap contracture. After 1 year, good results were observed in $67(87 \%)$ patients. Although results were suboptimal for 10 (13\%) patients, medical management offered good palliation, and reoperation was judged unnecessary by the patients themselves. No patient required outpatient or hospital dilation over the 1-year follow-up, since finger examination was possible in all patients.

Table 3 - Summary of literature review of anoplasty operations for anal stenosis.

\begin{tabular}{|c|c|c|c|c|}
\hline Author, year & Technique & Number of cases & Mean Follow-up (months) & Good results \\
\hline Gonzalez et al., ${ }^{1} 1995$ & S-plasty and advancement flaps & 17 & 18 & $94 \%$ \\
\hline Sarner, ${ }^{6} 1969$ & Sarner's flap & 21 & $\mathrm{Nr}$ & $100 \%$ \\
\hline Oh \& Zinberg, ${ }^{9} 1982$ & C-plasty & 12 & 12 & $92 \%$ \\
\hline Khubchandani, ${ }^{10} 1985$ & Mucosal flap & 53 & $\mathrm{Nr}$ & $94.1 \%$ \\
\hline Gingold \& Arvanitis, ${ }^{11} 1986$ & Y-V & 14 & $\mathrm{Nr}$ & $100 \%$ \\
\hline Milson \& Mazier, ${ }^{12} 1986$ & V-Y (1) and Sarner's (2) flap & 24 & Minimum: 1 & $90 \%(1) 75 \%(2)$ \\
\hline Caplin \& Kodner, ${ }^{13} 1986$ & Diamond flap & 7 & $\mathrm{Nr}$ & $100 \%$ \\
\hline Pearl et al., $1990^{15}$ & Island flaps (U or diamond) & 25 & 19 & $92 \%$ \\
\hline Habr-Gama et al., $1991^{16}$ & Sarner's and Musiari's flaps & 61 & 19 & $92 \%$ \\
\hline Angelchik et al., $1993^{17}$ & Y-V anoplasty or diamond flap & 14 & 12 & $100 \%$ \\
\hline Pidala et al., $1994^{18}$ & Island flap & 28 & 36 & $91 \%$ \\
\hline Sentovich et al., $1996^{19}$ & House flap & 21 & 28 & $90 \%$ \\
\hline Medeiros, $1997^{20}$ & Sarner's flap & 30 & $\mathrm{Nr}$ & $100 \%$ \\
\hline Maria et al., $1998^{21}$ & Y-V anoplasty or diamond flap & 42 & 24 & $93 \%$ \\
\hline Rakhmanine et al., $2002^{22}$ & Mucosal flap & 95 & 50 & $90 \%$ \\
\hline
\end{tabular}

$\mathrm{Nr}$ : not reported 


\section{CONCLUSION}

The ease of performance, good functional results, and lack of severe complications demonstrate that Sarner's and
Musiari's flap advancement techniques are effective and safe methods for surgical correction of anal stenosis, particularly when cutaneous fibrosis plays a major role in the etiology of anal stenosis.

\section{RESUMO}

HABR-GAMA e col. Tratamento cirúrgico da estenose anal:

Resultados de 77 anoplastias. CLINICS 60(1):17-20, 2005.

OBJETIVO: A estenose anal é uma condição rara, incapacitante e desafiadora que ocorre principalmente após hemorroidectomia, para a qual diversas técnicas cirúrgicas reparadoras foram desenvolvidas. $\mathrm{O}$ objetivo deste estudo é descrever os resultados precoces e tardios (um ano) de 77 anoplastias realizadas no Serviço de Cirurgia Colorretal.

MÉTODOS: No período de 1977 a 2002, 77 pacientes com estenose anal moderada ou grave foram operados, utilizando-se duas técnicas diferentes de avanço de retalho: 58 foram submetidos à técnica de Sarner e 18 submetidos à Técnica de Musiari. Avanços bilaterais foram utilizados em sete pacientes.
RESULTADOS: As complicações precoces foram: prurido em dois pacientes, infecção urinária em um paciente e incontinência fecal temporária em outro. Um paciente necessitou reoperação precoce por deiscência de linha de sutura. Os resultados tardios foram classificados como bons em 67 (87\%). Não houve reoperação por recorrência de estenose.

CONCLUSÃO: A facilidade técnica, os bons resultados funcionais e a ausência de complicações graves demonstraram que as técnicas de avanço de retalho de Sarner e Musiari são efetivas e seguras para correção de estenose anal, particularmente nos casos em que a fibrose cutânea é o principal fator etiológico.

\section{UNITERMOS: Estenose anal. Anoplastia. Retalho de} avanço.

\section{REFERENCES}

1. González AR, de oliveira O, Verzaro R, Nogueras J, Wexner SD. Anoplasty for stenosis and other anorectal defects. Am Surg 1995;61:526-9.

2. Lucthefeld M. Anal stenosis. Probl Gen Surg 2001;18:17-23.

3. Liberman H, Thorson AG. How I do it. Anal stenosis. Am J Surg 2000;179:325-9.

4. Musiari JP. Estenosis de ano. Sem Méd 1954;104:803-4.

5. Hudson AT. S-plasty repair of Whitehead deformity of the anus. Dis Colon Rectum 1967;10:57-60.

6. Sarner JB. Plastic relief of anal stenosis. Dis Colon Rectum $1969 ; 12: 277-80$

7. Corman ML, Veidenheimer MC, Coller JA. Anoplasty for anal stricture. Surg Clin North Am 1976;56:727-31.

8. Habr-Gama A, Alves PRA, Corsi A, Jatobá P, Teixeira MG, D'Albuquerque LA, et al. Sliding skin grafts in the treatment of anal strictures. Chir Gastroenterol 1978;12:277-83.

9. Oh C, Zinberg J. Anoplasty for anal stricture. Dis Colon Rectum 1982;25:809-10.

10. Khubchandani IT. Mucosal advancement anoplasty. Dis Colon Rectum 1985;28:194-6.

11. Gingold BS, Arvanitis M. Y-V anoplasty for treatment of anal stricture. Surg Gynecol Obstet 1986;162:241-2.

12. Milson JW, Maziew WP. Classification and management of postsurgical anal stenosis. Surg Gynecol Obstet 1986;163:60-4.
13. Caplin DA, Kodner IJ. Repair of anal stricture and mucosal ectropion by simple flap procedures. Dis Colon Rectum 1986;29:92-4.

14. Ramanujan PS, Venkatesh KS, Cohen M. Y-V anoplasty for severe anal stenosis. Contemp Surg 1988;33:62-8.

15. Pearl RK, Hooks VH, Abcarian H, Orsay CP, Nelson RL. Island flap anoplasty for the treatment of anal stricture and mucosal ectropion. Dis Colon Rectum 1990;33:581-3.

16. Habr-Gama A, Alves PRA, Rodrigues LV, Vieira MJF. Anoplastia para tratamento da estenose anal. Rev Bras Colo-proctol $1991 ; 11: 15-8$.

17. Angelchik PD, Harms BA, Starling JR. Repair of anal stricture and mucosal ectropion with $\mathrm{Y}-\mathrm{V}$ or pedicle flap anoplasty. Am J Surg 1993;166:55-9.

18. Pidala MJ, Slezak FA, Porter JA. Island flap anoplasty for anal canal stenosis and mucosal ectropion. Am Surg 1994;60:194-6.

19. Sentovich SM, Falk PM, Christensen MA, Thorson AG, Blatchford GJ, Pitsch RM. Operative results of House advancement anoplasty. Br J Surg 1996;83:1242-4.

20. Medeiros RR. Estenose anal: análise de 30 casos. Rev Bras Coloproctol 1997;17:24-6.

21. Maria G, Brisinda G, Civello IM. Anoplasty for the treatment of anal stenosis. Am J Surg 1998;175:158-60.

22. Rakhmanine M, Rosen L, Khubchandani I, Stasik J, Riether RD. Lateral mucosal advancement anoplasty for anal stricture. Br J Surg 2002;89:1423-4. 